\title{
Cycloclasticus pugetii gen. nov., sp. nov., an Aromatic Hydrocarbon-Degrading Bacterium from Marine Sediments
}

\author{
SHERYL E. DYKSTERHOUSE, † JAMES P. GRAY, RUSSELL P. HERWIG, \\ J. CANO LARA, AND JAMES T. STALEY \\ Department of Microbiology, SC-42, University of Washington, Seattle, Washington 98195
}

\begin{abstract}
Three heterotrophic bacterial strains were isolated from different locations in Puget Sound, Washington, by using biphenyl as the principal carbon source. These strains grow by using a limited number of organic compounds, including the aromatic hydrocarbons naphthalene, phenanthrene, anthracene, and toluene, as sole carbon sources. These aerobic, gram-negative rods are motile by means of single polar flagella. Their $16 \mathrm{~S}$ rRNA sequences indicate that they are all members of the $\gamma$ subdivision of the Proteobacteria. Their closest known relatives are the genera Methylobacter and Methylomonas (genera of methane-oxidizing bacteria), uncultured sulfur-oxidizing symbionts found in marine invertebrates, and clone FL5 containing 16S ribosomal DNA amplified from an environmental source. However, the Puget Sound bacteria do not use methane or methanol as a carbon source and do not oxidize reduced sulfur compounds. Furthermore, a 16S rRNA base similarity comparison revealed that these bacteria are sufficiently different from other bacteria to justify establishment of a new genus. On the basis of the information summarized above, we describe a new genus and species, Cycloclasticus pugetii, for these bacteria; strain PS-1 is the type strain of $C$. pugetii.
\end{abstract}

Nearshore marine environments receive a wide variety of recalcitrant organic compounds, including hydrocarbons from shipping activities, terrestrial and freshwater runoff and pollution, sewage, and accidental spillage of fuels and other petroleum products. The aliphatic fraction of petroleum hydrocarbons tends to be more easily degraded than the aromatic compounds. Polycyclic aromatic hydrocarbons (PAHs) are of particular concern because of their persistence and toxicity. Many of these compounds are known to be mutagenic and are suspected carcinogens. Because of their relatively poor solubility in water and hydrophobic nature, PAHs strongly adsorb to particulate material, settle to the seafloor, and accumulate in marine sediments. High concentrations of toxic contaminants in sediments have been correlated with a high incidence of histopathological abnormalities in bottomfish, toxicity to sediment infauna, and other adverse effects $(41,42)$. In Puget Sound and in many other areas of the world, another source of $\mathrm{PAH}$ pollution has been the wood products industry; many sites are contaminated with creosote, a wood preservative that is primarily composed of PAHs (33).

Despite their refractory nature, hydrocarbons are degraded by microbial activity in marine environments. Alkane degradation has been studied most thoroughly, and degradation of PAHs has also been described (28). Although most of the research on the microbiology of PAH degradation has focused on a few Pseudomonas species, other bacterial genera whose members have been reported to degrade PAHs include the genera Aeromonas, Flavobacterium, Beijerinckia, Alcaligenes, Micrococcus, Vibrio, Flavobacterium, and Mycobacterium (13, $18,20,21,24,25,32,34,43)$.

In this paper we describe the isolation and characterization of three strains of bacteria obtained from Puget Sound sediments that are capable of growing on aromatic hydrocarbons

\footnotetext{
* Corresponding author. Phone: (206) 685-2163. Fax: (206) 5438297. Electronic mail address: herwig@u.washington.edu.

† Present address: 67th Evac Hospital, Unit 26610, P.O. Box 369, APO AE 09244.
}

as their sole sources of organic carbon. These strains grow on a limited number of carbon sources and are not members of any previously described genus.

\section{MATERIALS AND METHODS}

Sediment sampling. Samples of marine sediments were collected from the following three sites in Puget Sound, Washington: Sinclair Inlet, near the city of Bremerton (site 1), a site adjacent to Pier 62 in Seattle (site 2), and the Duwamish River in Seattle (site 3). These sites were selected because they were known to contain at least $1 \mathrm{ppm}$ of polychlorinated biphenyls $(1 \mathrm{mg}$ of polychlorinated biphenyls per $\mathrm{kg}$ ). Site 1 samples were collected with a Van Veen grab apparatus from a boat, site 2 samples were collected by lowering a handheld Van Veen grab apparatus from the side of Pier 62, and site 3 samples were removed from a Vibracore sample. The samples used in this study were aseptically collected from the upper $3 \mathrm{~cm}$ of sediment. The salinity of the overlying water was determined by using a Cambridge Hand Refractometer (Reichert-Jung), and temperature was measured with a thermometer. Samples were stored on ice until they were returned to the laboratory and thereafter were maintained at $4^{\circ} \mathrm{C}$ until they were inoculated onto media.

Media. An artificial seawater mineral salts medium (ONR7a) based on the ionic composition of seawater (5) was used in this study. This medium contained all of the major cations and anions that are present at concentrations greater than $1 \mathrm{mg} /$ liter in seawater. Nitrogen was provided in the form of $\mathrm{NH}_{4} \mathrm{Cl}$, and phosphorous was provided in the form of $\mathrm{Na}_{2} \mathrm{HPO}_{4}$. ONR7a contained (per liter of distilled or deionized water) $22.79 \mathrm{~g}$ of $\mathrm{NaCl}, 11.18 \mathrm{~g}$ of $\mathrm{MgCl}_{2} \cdot 6 \mathrm{H}_{2} \mathrm{O}, 3.98 \mathrm{~g}$ of $\mathrm{Na}_{2} \mathrm{SO}_{4}, 1.46 \mathrm{~g}$ of $\mathrm{CaCl}_{2} \cdot 2 \mathrm{H}_{2} \mathrm{O}, 1.3 \mathrm{~g}$ of TAPSO $\{3-[\mathrm{N}$-tris(hydroxymethyl) methylamino]-2-hydroxypropanesulfonic acid\}, $0.72 \mathrm{~g}$ of $\mathrm{KCl}, 0.27 \mathrm{~g}$ of $\mathrm{NH}_{4} \mathrm{Cl}$, $89 \mathrm{mg}$ of $\mathrm{Na}_{2} \mathrm{HPO}_{4} \cdot 7 \mathrm{H}_{2} \mathrm{O}, 83 \mathrm{mg}$ of $\mathrm{NaBr}, 31 \mathrm{mg}$ of $\mathrm{NaHCO}_{3}, 27 \mathrm{mg}$ of $\mathrm{H}_{3} \mathrm{BO}_{3}$, $24 \mathrm{mg}$ of $\mathrm{SrCl}_{2} \cdot 6 \mathrm{H}_{2} \mathrm{O}, 2.6 \mathrm{mg}$ of $\mathrm{NaF}$, and $2.0 \mathrm{mg}$ of $\mathrm{FeCl}_{2} \cdot 4 \mathrm{H}_{2} \mathrm{O}$. To prevent precipitation of ONR7a during autoclaving, three separate solutions were prepared and then mixed together after autoclaving when the solutions had cooled to at least $50^{\circ} \mathrm{C}$; one solution contained $\mathrm{NaCl}, \mathrm{Na}_{2} \mathrm{SO}_{4}, \mathrm{KCl}, \mathrm{NaBr}$, $\mathrm{NaHCO}_{4}, \mathrm{H}_{3} \mathrm{BO}_{3}, \mathrm{NaF}, \mathrm{NH}_{4} \mathrm{Cl}, \mathrm{Na}_{2} \mathrm{HPO}_{4}$, and TAPSO ( $\mathrm{pH}$ adjusted to 7.6 with $\mathrm{NaOH}$ ), the second solution contained $\mathrm{MgCl}_{2}, \mathrm{CaCl}_{2}$, and $\mathrm{SrCl}_{2}$ (divalent cation salts), and the third solution contained $\mathrm{FeCl}_{2}$. For solid media, Bacto Agar (Difco) (15.0 g/liter) or agarose (Sigma) (12.0 g/liter) was added to the first solution.

For the initial isolation of biphenyl-degrading bacteria, small amounts of yeast extract, peptone, trace minerals, or vitamins were added to ONR7a. Later, these supplements were found to be unnecessary and were not added to the media. ONR8a contained the compounds listed above for ONR7a plus $10 \mathrm{ml}$ of a vitamin solution (40) per liter and $10 \mathrm{ml}$ of ONR trace element solution per liter. The formula of ONR trace element solution was the same as the formula of the trace element solution of Shelton and Tiedje (39), except that $\mathrm{FeCl}_{2}$ was not included in ONR trace element solution, the concentration of $\mathrm{Na}_{2} \mathrm{MoO}_{4} \cdot 2 \mathrm{H}_{2} \mathrm{O}$ was increased to $0.1 \mathrm{mg} /$ liter, and $\mathrm{Na}_{2} \mathrm{WoO}_{4} \cdot 2 \mathrm{H}_{2} \mathrm{O}$ was added at a concentra- 
tion of $0.10 \mathrm{mg} /$ liter. ONR8a + YE contained the compounds in ONR8a plus 0.05 $\mathrm{g}$ of yeast extract (Difco) per liter, and ONR8a+YEP contained the compounds in ONR8 $\mathrm{a}+$ YE plus $0.05 \mathrm{~g}$ of peptone (Difco) per liter.

Isolation of biphenyl-degrading bacteria. A $10-\mathrm{g}$ portion of sediment and 40 $\mathrm{ml}$ of ONR7a were mixed in a Waring blender for $1 \mathrm{~min}$ at a power setting of $50 \%$. The supernatant was then diluted $(1: 5)$ with ONR7a, and $0.2 \mathrm{ml}$ of the resulting preparation was spread onto a ONR8a + YE agar plate. Approximately $0.2 \mathrm{~g}$ of biphenyl (Aldrich, Milwaukee, Wis.) was placed on the petri dish lid, and the inoculated medium was incubated inverted at room temperature. Colonies surrounded by a diffusible yellow zone were streaked onto ONR8a + YEP plates. Previous investigators have observed the formation of a diffusible yellow color during microbial degradation of biphenyl and have shown that this color is caused by a meta-cleavage product (1). Control plates without biphenyl were also inoculated.

Phenotypic testing. Cultures isolated on plates containing biphenyl that produced a yellow diffusible product were examined for a variety of phenotypic properties. All of the compounds used in this study were reagent quality or better. To determine whether different substrates could be used as sole sources of carbon, representative carbohydrates, amino acids, phenol, and possible key intermediate metabolic compounds were added at concentrations between 0.1 and $0.2 \%$ (mass/volume for solid substrates, volume/volume for liquid substrates) to ONR7a broth. Because of their toxicity or solubility, some substrates were tested at lower concentrations. For carbon source usage tests the concentration of TAPSO in ONR7a was increased to $25 \mathrm{mM}$ to enhance the buffering capacity of the media. Unless indicated otherwise, inoculated media were incubated at room temperature, and cultural growth was observed periodically for 3 weeks. Media that did not contain an added carbon source were used as controls. The carbohydrates tested included glucose, fructose, arabinose, and ribose. The aromatic hydrocarbons tested included biphenyl, naphthalene, phenanthrene, anthracene, toluene, and phenol. Growth on biphenyl, naphthalene, phenanthrene, or anthracene was examined by adding crystals (approximately $3 \mathrm{mg} / \mathrm{ml}$ ) directly to ONR7a broth. Growth on toluene was tested by inoculating ONR7a agarose plates and placing the cultures in 1.0,10.0, and 100\% toluene-saturated atmospheres in glass desiccator jars (11). Phenol was tested at concentrations of $0.1,0.01$, and $0.001 \%$ (vol $/ \mathrm{vol})$. Each organic acid was tested by adding its sodium salt to ONR7a broth. The organic acids tested included acetate, butyrate, propionate, benzoate, salicylate, lactate, and pyruvate. We also examined growth on ethanol, methanol, formaldehyde, glucosamine, hexadecane, and mannitol. Growth on methane was tested by inoculating ONR7a and Bacto Marine 2216 broth (Difco) plates and placing them in a BBL GasPak jar. The gas within the jar was then replaced with a $30 \%$ methane- $70 \%$ air atmosphere.

For other phenotypic tests, cultures were grown in ONR7a broth containing crystals of biphenyl. Biphenyl was added to all complex media because growth of the biphenyl-degrading isolates was always enhanced in its presence. Gram stain reactions were determined by using a modification of the method described by Manafi and Kneifel (29) and L-alanine-7-amido-4-methyl-coumarin trifluoroacetate (AMCT). Cultures in the log phase of growth were streaked onto the surfaces of Whatman no. 1 filter papers that were soaked with a solution containing $500 \mu \mathrm{g}$ of AMCT per ml of distilled water. Each filter paper was allowed to dry and placed on a UV transilluminator. Gram-negative cells fluoresced, and gram-positive cells did not. Oxidase, catalase, and amylase activity, gelatin hydrolysis, lipase activity and nitrate reduction tests and the test to determine sensitivity to vibriostatic agent 0/129 (Oxoid) were performed as previously described (17). Tween 80 (Sigma) was used in the lipase test medium. The concentration of gelatin in the gelatin hydrolysis test medium was increased to $1 \%$ to simplify interpretation of the results. Luminescence was examined by using Bacto Marine 2216 agar supplemented with 3\% (vol/vol) glycerol. A modified marine oxidative-fermentative test was performed by using the ONR7a formula for artificial seawater and $0.5 \%$ glucose. To determine nitrate reduction, organisms were grown in Bacto Marine 2216 broth supplemented with $0.1 \%$ $\mathrm{KNO}_{3}$ and $0.17 \%$ Bacto Agar. The nitrate reduction test was performed after 1 week of incubation. CLED agar (Oxoid) (22) was used to determine whether $\mathrm{NaCl}$ was required for growth.

The effects of $\mathrm{pH}$, salinity, and temperature on growth were also examined. To determine the $\mathrm{pH}$ range for growth, ONR7a was prepared with the following buffers (Sigma): $25 \mathrm{mM}$ 2-( $N$-morpholino)ethanesulfonic acid (MES), $\mathrm{pH} 5.5 ; 25$ $\mathrm{mM} \mathrm{N}$-(2-acetamido)-2-aminoethanesulfonic acid (ACES), $\mathrm{pH} 6.5 ; 25 \mathrm{mM}$ TAPSO, pH 7.6; $25 \mathrm{mM}$ tris(hydroxymethyl)-methylaminopropanesulfonic acid

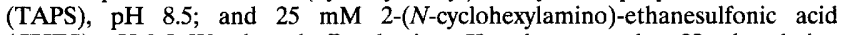
(CHES), $\mathrm{pH} 9.5$. We chose buffers having $\mathrm{pK}_{\mathrm{a}}$ values near the $\mathrm{pH}$ values being examined. To determine the salinity range for growth, ONR7a broth was prepared by adjusting the concentrations of the inorganic salts (except $\mathrm{NH}_{4} \mathrm{Cl}$, $\mathrm{Na}_{2} \mathrm{HPO}_{4}, \mathrm{FeCl}_{2}$, and TAPSO, which were kept at constant levels) so that the levels of salinity were $0.35,3.5,10,18,35$, and $70 \%$; these values ranged from 0.01 to 2 times the level of salinity of seawater. Biphenyl crystals were added to the broth prior to inoculation. To determine the temperature range for growth, Bacto Marine 2216 and ONR7a plates containing biphenyl crystals were incubated at the following temperatures: $4,15,22,28$, and $37^{\circ} \mathrm{C}$.

The motility and cellular morphology of the isolates were determined by examining cultures grown in Bacto Marine 2216 and ONR7a broth media containing biphenyl crystals with a phase-contrast microscope. Flagella were detected by examining negatively stained cells grown in ONR7a broth containing biphenyl with an electron microscope. Cells were fixed with $3 \%$ glutaraldehyde for $20 \mathrm{~min}$ at room temperature and spotted onto 300 -mesh carbon-coated electron microscope grids. The cells were washed with distilled water and negatively stained with $2 \%$ phosphotungstic acid $(\mathrm{pH} 7.35)$ for $15 \mathrm{~s}$.

Thin sections of the strains were prepared to determine cell ultrastructure. Cells were fixed in ONR7a broth containing 3\% glutaraldehyde and $0.2 \%$ ruthenium red at $4^{\circ} \mathrm{C}$ for $2 \mathrm{~h}$. The cells were washed with ONR7a containing $0.1 \%$ ruthenium red, mixed with $1.5 \%$ molten Noble agar (Difco), and fixed with $1.0 \%$ osmium tetroxide containing $0.05 \%$ ruthenium red for $2 \mathrm{~h}$ at room temperature. After the cells were washed with cacodylate buffer, they were dehydrated by using a graded series of ethanol and were embedded in Med Cast resin. Thin sections were stained with uranyl acetate and lead citrate. Preparations of negatively stained cells and thin sections were examined with a JOEL model 1200 EX II transmission electron microscope operated at $80 \mathrm{kV}$.

Whole-cell fatty acid analysis. Whole-cell fatty acid analyses were performed by growing cells in $50 \mathrm{ml}$ of Bacto Marine 2216 broth containing biphenyl crystals for 3 days with agitation $(220 \mathrm{rpm})$. The cultures were centrifuged for $10 \mathrm{~min}$ at $3,000 \times g$. Each resulting pellet was washed twice with $15 \mathrm{ml}$ of ONR7a broth, and approximately $40 \mathrm{mg}$ (wet weight) of cells was used for the analysis. Cellular fatty acids were extracted, methylated, and detected with a Hewlett Packard model 5890 Series II gas chromatograph as previously described (31).

Control bacterial strains. Cultures of the following organisms were used as controls in the phenotypic and whole-cell fatty acid analyses: Escherichia coli ATCC 25922, Bacillus cereus (teaching strain; Department of Microbiology, University of Washington, Seattle), Pseudomonas aeruginosa ATCC 27853, Vibrio metschnikovii ATCC 7708, Vibrio parahaemolyticus ATCC 17802, Aeromonas salmonicida ATCC 33658, Oceanospirillum linum ATCC 11336, Alteromonas macleodii ATCC 27126, Marinomonas vaga ATCC 27119, Thiobacillus thioparus ATCC 8158, Methylomonas methanica ATCC 35067, and Methylosinus trichosporium ATCC 35070

$\mathbf{G}+\mathbf{C}$ contents. The guanine-plus-cytosine $(\mathrm{G}+\mathrm{C})$ contents of the isolates were determined by using the high-performance liquid chromatography method described previously (17). Genomic DNA was prepared by using a miniprep procedure that included hexadecytrimethylammonium bromide precipitation (2). E. coli and purified lambda phage DNA (Sigma) were used as controls.

Phylogenetic analysis. To perform a phylogenetic analysis of the biphenyldegrading strains, 16S ribosomal DNA (rDNA) was isolated, cloned, and sequenced. Total genomic DNA was isolated from $1.5 \mathrm{ml}$ of late-exponentialphase cells grown in ONR7a broth containing biphenyl crystals by using InstaGene (Bio-Rad), and the amount of total genomic DNA was determined by fluorimetry. PCR amplification of the $16 \mathrm{~S}$ rRNA gene was performed by using a modification of the reaction conditions and universal primers 8FPL and 1492RPL described by Reysenbach et al. (37). The Tris $\mathrm{HCl}$ concentration in the $10 \times$ reaction buffer was increased to $300 \mathrm{mM}$, and $5 \%$ acetamide was added (3). The concentration of each deoxynucleoside triphosphate was adjusted to 200 $\mu \mathrm{M}, 2.5 \mathrm{U}$ of Taq polymerase was used, and the concentrations of both PCR primers were adjusted to $500 \mathrm{nM}$. The temperature parameters used were as follows: 29 cycles consisting of $1.5 \mathrm{~min}$ at $93^{\circ} \mathrm{C}, 1.5 \mathrm{~min}$ at $42^{\circ} \mathrm{C}$, and 1.5 -min ramps to $72^{\circ} \mathrm{C}$, followed by $2 \mathrm{~min}$ at $72^{\circ} \mathrm{C}$, with $5 \mathrm{~s}$ added to each cycle. A 30th cycle included $7 \mathrm{~min}$ of extension at $72^{\circ} \mathrm{C}$ (3). The reaction products were digested with NotI, isolated on $1 \%$ low-melting-point agarose (Sigma) gels, ligated into dephosporylated pBlueScript (Stratagene, La Jolla, Calif.), and transformed into $E$. coli DH5 $\alpha$. The cloned genes were then sequenced with a Taq DyeDeoxy terminator cycle sequencing kit (Applied Biosystems, Foster City, Calif.). The sequencing primers used included pBlueScript vector primers KS and M13 (-20) (Stratagene) and the following forward and reverse internal primers (15): SP3 (positions 338 to 357 [E. coli $16 \mathrm{~S}$ rDNA sequence numbering]; ACTCCTACGGGAGGCAGCAG), SP5 (positions 519 to 536; CAGCAGCtG CGGTAATAC), SP7 (positions 785 to 805; GGATTAGATACCCTGGTAG TCC), SP11 (positions 1101 to 1115; AACGAGCGCAACCCT), SP13 (positions 1391 to 1406; TGTACACACCGCCCGT), SP3R (positions 536 to 519; ACTG CaGCCTCCCGTAGGA), SP5R (positions 536 to 519; GTATTACCGCGGCT GCTG), SP7R (positions 806 to 785; TACCAGGGTATCTAATCC), SP11R (positions 1115 to 1101; AGGGTTGCGCGCGTT), and SP13R (positions 1406 to 1391; ACGGGCaGTGTGTACA) (the bases in lowercase letters are bases that are different from the bases in the $E$. coli $16 \mathrm{~S}$ rDNA sequence [7]).

16S rDNA sequences were assembled by using the Fragment Assembly programs available from the Genetics Computer Group (GCG) (16). Sequence information and preliminary alignments were retrieved by using the electronic mail server at the Ribosomal Database Project (RDP) (27). The strain PS-1 ${ }^{\mathrm{T}}$ (T = type strain) $16 \mathrm{~S}$ rDNA sequence was compared with the small-subunit rRNA sequences by submitting an inquiry and using the program SIMILARITY RANK. The RDP sequences were retrieved by using the program SUBALIGNMENT, and preliminary alignment of the sequences of the biphenyl-degrading organisms was completed by using the program ALIGN_SEQUENCE. All sequences were examined and minor alignment adjustments were made by using the sequence editor SeqApp (19) and a Macintosh computer.

Our phylogenetic analysis was completed by using the computer program fastDNAml (36). The aligned sequences and program options were submitted as a batch file to the University of Washington Unix computer called mead (IBM AIX). Category rates were determined by randomly selecting 37 different bacterial sequences from the sequences of members of the $\gamma$ subdivision of the 
TABLE 1. Sources and characteristics of 16S rDNA sequences used for phylogenetic analysis in this study

\begin{tabular}{|c|c|c|c|c|}
\hline Source & RDP $\operatorname{code}^{a}$ & $\begin{array}{l}\text { GenBank } \\
\text { accession no. }\end{array}$ & $\begin{array}{l}\text { Sequence length without } \\
\text { gaps (bases) }\end{array}$ & $\begin{array}{l}\text { Reference for } \\
\text { sequence }\end{array}$ \\
\hline Methylomonas methanica ATCC 35067 & Mlm.methal & $\mathrm{ND}^{b}$ & 1,481 & 44 \\
\hline Methylomonas rubra & Mlm.rubra & M95662 & 1,471 & 6 \\
\hline Methylobacter luteus NCIMB 11914 & Mbc.luteus & M95657 & 1,362 & 6 \\
\hline Gill symbiont of Lucinoma aequizonata & sym.Lucnae & M99448 & 1,340 & 9 \\
\hline Gill symbiont of Thyasira flexuosa & sym.Thya.f & L01575 & 1,497 & 10 \\
\hline Gill symbiont of Bathymodiolus thermophilus & sym.Bath.t & M99445 & 1,375 & 9 \\
\hline Gill symbiont of Solemya reidi & sym.Solm.r & L07864 & 1,200 & 10 \\
\hline Chromatium vinosum ATCC 17899 & Chr.vinosm & M26629 & 1,494 & 44 \\
\hline Piscirickettsia salmonis & Psr.salmon & $\mathrm{X} 60783$ & 1,531 & 12 \\
\hline Coxiella burnetii Q177 & Cox.burnet & M21291 & 1,484 & 44 \\
\hline Marinobacter hydrocarbonoclasticus ATCC 49840 & Mrb.hyclas & $\mathrm{X} 67022$ & 1,483 & 14 \\
\hline Thiomicrospira thyasiris DSM 5322 & Tms.thyasi & L01478 & 1,348 & 10 \\
\hline Oceanospirillum jannaschii ATCC 27135 & Osp.jannas & ND & 1,490 & 44 \\
\hline Alteromonas haloplanktis ATCC 14393 & Altm.halop & X67024 & 1,465 & 14 \\
\hline Aeromonas trota ATCC 49657 & Arm.trota & X60415 & 1,502 & 30 \\
\hline Vibrio mimicus ATCC 33653 & V.mimicus & X74713 & 1,457 & 38 \\
\hline Escherichia coli $\mathrm{K}-12$ substrain MG1655 & E.coli & J01695 & 1,539 & 7 \\
\hline Environmental clone FL5 & env.FL5_2 & L10936 & 1,332 & 8 \\
\hline
\end{tabular}

a Sequence code used in RDP version 4.0 (19 June 1994) of the RDP database electronic mail server.

${ }^{b} \mathrm{ND}$, no data available.

Proteobacteria and creating a maximum-likelihood tree with fastDNAml. The tree that was generated and the aligned sequences were used to determine rates by using the program DNAml_rates_1_0 (35). Using the rates that were calculated with this program, we repeated this process two more times. The rates calculated after the third cycle were used in our maximum-likelihood analysis of the Puget Sound biphenyl-degrading isolates. The following fastDNAml program options were selected: the program was repeated with 100 bootstrap samples, and for the current bootstrap seed the addition of organisms was jumbled a maximum of 10 times until the same best tree was found three times. The frequencies of bases were empirically determined, and each position was weighted with a value of 0 or 1 . A position was weighted with a value of 0 if more than one-half of the sequences contained a missing base or gap at that position. Representative members of the $\gamma$ subdivision of the Proteobacteria, including organisms suspected of being closely related, were included in the phylogenetic analysis. Table 1 shows the sources of the 16S rDNA sequences used in this study. All of the sequences were at least 1,200 bases long.

A 16S rRNA homology matrix for sequences previously aligned for the phylogenetic analysis was generated by using the GCG (16) programs Pileup and Distances. Pileup was used to generate a multiple sequence containing all listed strains and was forced to retain the alignments and gaps used for the fastDNAml analysis. The matrix was then generated by using this multiple sequence file in the program Distances.

Nucleotide sequence accession numbers. The $16 \mathrm{~S}$ rDNA sequence of strain PS- $1^{\mathrm{T}}$ has been deposited in the GenBank and Genome Sequence DataBase sequence collections under accession numbers U12624 and L34955, respectively. Other accession numbers are shown in Table 1.

\section{RESULTS}

Collection of samples and isolation of bacteria. Sediment samples were collected from three different sites on Puget Sound. The sampling dates, water temperatures, and levels of salinity of the samples were as follows: site 1, 22 July 1991, $16^{\circ} \mathrm{C}, 32 \%$; site 2,29 July $1991,12^{\circ} \mathrm{C}, 31 \%$; and site 3,6 August $1991,16^{\circ} \mathrm{C}, 22 \%$.

Colonies that produced a yellow diffusible compound during the initial isolation and after restreaking were selected for further study. One strain was selected from each sediment site, and these strains were designated PS- ${ }^{\mathrm{T}}$, PS-2, and PS-3 (isolated from Puget Sound sites 1, 2, and 3, respectively).

Phenotypic characteristics. In general, the three strains isolated from Puget Sound produced identical results in the phenotypic tests. PS- $1^{\mathrm{T}}$, PS-2, and PS-3 cells were aerobic, gram-negative, catalase-positive, oxidase-positive, motile rods that were 0.5 by 1.0 to $2.0 \mu \mathrm{m}$. These strains did not produce endospores and required $\mathrm{NaCl}$ and the divalent cations present in ONR7a for growth. Nitrate was reduced to nitrite. The cultures grew at temperatures ranging from 4 to $28^{\circ} \mathrm{C}$, in the presence of levels of salinity ranging from 10 to $70 \%$, and at $\mathrm{pH}$ values ranging from 6.5 to 9.5 for PS- ${ }^{\mathrm{T}}$ and PS-2 and from 6.5 to 8.5 for PS-3. Transmission electron microscopy of whole cells revealed that each cell of all three strains had a single polar flagellum with several fimbriae originating from the cell surface (Fig. 1A). Each flagellar filament was $13 \mathrm{~nm}$ in diameter, and the diameter of the fimbriae was $6 \mathrm{~nm}$. Thin sections revealed that PS- ${ }^{\mathbf{T}}$, PS-2, and PS- 3 had a cell envelope structure typical of gram-negative bacteria (Fig. 1B).

The following aromatic hydrocarbons, fatty acids, and amino acid were utilized as sole sources of carbon by PS- $1^{\mathrm{T}}$, PS-2, and PS-3 in ONR7a broth: biphenyl, naphthalene, anthracene, phenanthrene, salicylate, toluene, benzoate, acetate, propionate, and glutamate. Growth was not observed on the following one-carbon compounds, hydrocarbons, organic acids, amino acids, intermediates, and carbohydrates: methane, methanol, formaldehyde, ethanol, hexadecane, lactate, mannitol, alanine, phenylalanine, proline, tryptophan, tyrosine, $\alpha$-ketoglutarate, malate, citrate, pyruvate, butyrate, glucose, fructose, and ribose. PS- $1^{\mathrm{T}}$, PS-2, and PS-3 produced lipase, but did not secrete amylase and did not hydrolyze gelatin.

Some minor differences were observed in the whole-cell fatty acid compositions of the three strains (Table 2). For example, stearic acid (18:0) was detected only in strain PS $-1^{\mathrm{T}}$, and strain PS-2 lacked summed feature 18:1. The predominant fatty acids in all three strains were similar; $16: 1 \omega 7$ cis was the most prevalent fatty acid.

$\mathbf{G}+\mathbf{C}$ contents and phylogenetic analysis. The $\mathrm{G}+\mathrm{C}$ contents of PS-1 ${ }^{\mathrm{T}}$, PS-2, and PS-3 ranged from 37 to $38 \mathrm{~mol} \%$. The $16 \mathrm{~S}$ rDNA sequences of these isolates were nearly identical and indicated that the organisms are members of the $\gamma$ subdivision of the Proteobacteria. Using a maximum-likelihood method of phylogenetic analysis, we constructed the tree shown in Fig. 2 by using a transition/transversion ratio of 1.5, a ratio which yielded a higher log likelihood value than ratios of 1.0 or 2.0. Strains PS-1 ${ }^{\mathrm{T}}$, PS-2, and PS-3 were found to be phylogenetically most closely related to a clone containing an amplified $16 \mathrm{~S}$ rDNA gene obtained from a marine water column sample retrieved from the Santa Barbara channel (clone FL5) (8), Methylomonas methanica, Methylobacter lu- 

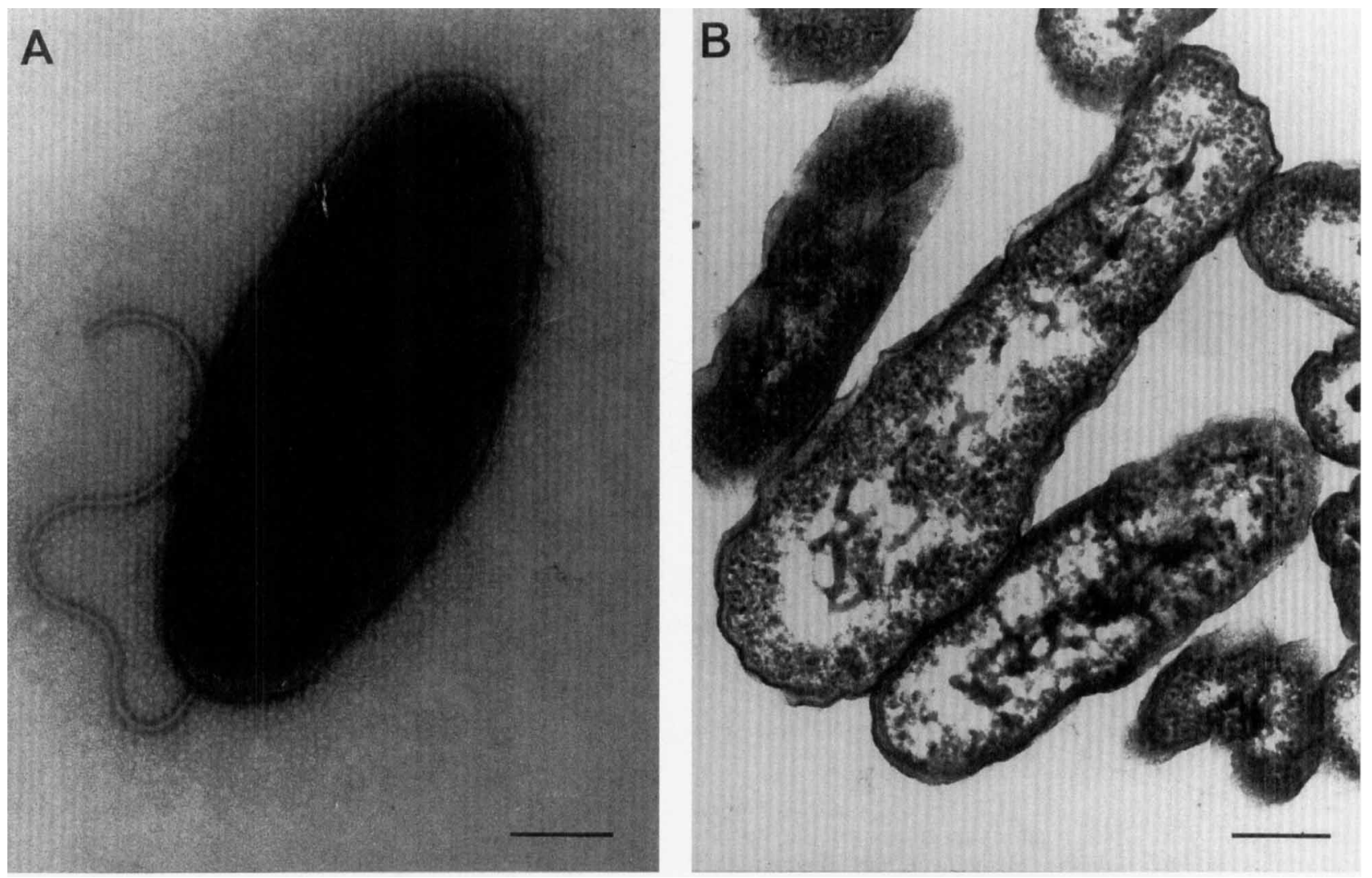

FIG. 1. (A) Negatively stained preparation of a PS-1 $1^{\mathrm{T}}$ cell showing the single polar flagellum and fimbriae originating from the cell surface. (B) thin section of PS-1 ${ }^{\mathrm{T}}$ cells showing the cell envelope typical of a gram-negative bacterium. Bars $=200 \mathrm{~nm}$.

teus, and sulfur-oxidizing symbionts obtained from the marine invertebrates Lucinoma aequizonata and Thyasira flexuosa. The $\log$ likelihood value for the tree shown in Fig. 2 was $-7211.435055637$.

A similarity matrix derived from the gapped $16 \mathrm{~S}$ rDNA sequences is shown in Table 3 . None of the sequences used to generate the phylogenetic tree exhibited a level of similarity with the PS-1 ${ }^{\mathrm{T}}$ sequence that was greater than 0.900 . The highest similarity values were found when we compared PS- $1^{\mathrm{T}}$ with Methylomonas methanica (0.8937), environmental clone FL5 (0.8919), and a gill symbiont of Thyasira flexuosa $(0.8902)$.

TABLE 2. Whole-cell fatty acid compositions of PS- $1^{\mathrm{T}}$, PS-2, and PS-3

\begin{tabular}{lccc}
\hline \multirow{2}{*}{ Fatty acid } & \multicolumn{3}{c}{ \% of total fatty acids in: } \\
\cline { 2 - 4 } & Strain PS-1 $^{\mathrm{T}}$ & Strain PS-2 & Strain PS-3 \\
\hline 10:0 3OH & 1.03 & 1.09 & 0.94 \\
Unknown $^{a}$ & 5.96 & 5.94 & 5.83 \\
$12: 0$ & 2.46 & 3.30 & 3.06 \\
$12: 03 \mathrm{OH}$ & 2.80 & 3.06 & 2.61 \\
$14: 0$ & 0.29 & 1.21 & 0.62 \\
$16: 1 \omega 5$ cis & 0.41 & 0.55 & 0.49 \\
$16: 1 \omega 7$ cis & 61.5 & 60.2 & 60.9 \\
16:0 & 23.0 & 24.7 & 24.6 \\
Summed feature $18: 1^{b}$ & 2.18 & & 0.55 \\
18:0 & 0.41 & & \\
\hline
\end{tabular}

${ }^{a}$ Unidentified peak at an equivalent carbon length of 11.798 .

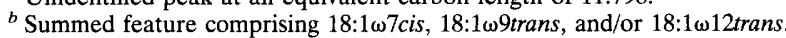

The phylogenetic placement of PS $-1^{\mathbf{T}}$ within the $\gamma$ subdivision of the Proteobacteria is not particularly robust. A majority rule consensus tree was generated by performing a bootstrap analysis of the data in which the data were bootstrapped more than 100 times. In the consensus tree, PS- $1^{\mathrm{T}}$ associated with environmental clone FL5 in only $60 \%$ of the bootstraps. In the consensus analysis of the bootstrapped data the PS- $1^{\mathrm{T}}$ and FL5 sequences clustered with Thiomicrospira thyasiris $48 \%$ of the time, whereas in the best tree (Fig. 2) Thiomicrospira thyasiris came off of the Oceanospirillum jannaschii branch. The results of another analysis of the PS- $1^{\mathrm{T}}$ sequence in which the RDP program CHECK_CHIMERA was used, suggested that the precise ancestry of PS-1 ${ }^{\mathrm{T}}$ 16S rRNA may be difficult to determine since one portion of the PS- $1^{\mathbf{T}}$ molecule appears to be more similar to Methylomonas methanica $16 \mathrm{~S}$ rRNA and another portion appears to be more similar to Alteromonas haloplanktis 16S rRNA.

\section{DISCUSSION}

On the basis of the results of phenotypic analyses (obligately aerobic growth, Gram stain negative, rod shape, motility by means of a single polar flagellum, and isolation from marine sources), as well as their low $\mathrm{G}+\mathrm{C}$ contents, $\mathrm{PS}-1^{\mathrm{T}}, \mathrm{PS}-2$, and PS-3 were initially thought to be members of the genus Alteromonas $(4,23,26)$. However, the results of a $16 \mathrm{~S}$ rRNA phylogenetic analysis clearly indicated that this placement was incorrect. Instead, the closest relatives of these organisms are members of the methane-oxidizing genera Methylomonas and Methylobacter, a group of sulfur-oxidizing symbionts found in marine invertebrates, and a $16 \mathrm{~S}$ rRNA environmental clone 


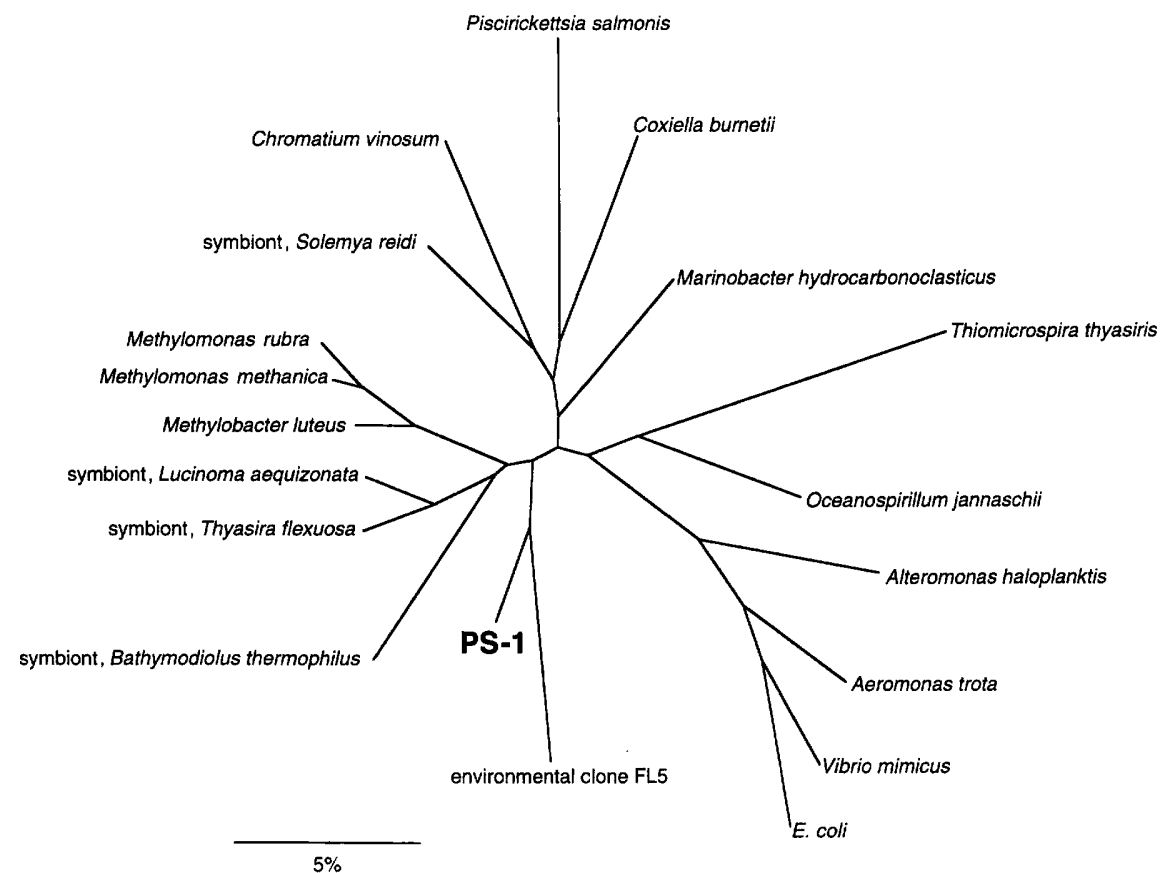

FIG. 2. Phylogenetic tree constructed by a maximum-likelihood method of analysis for $C$. pugetii PS- $\mathrm{1}^{\mathrm{T}}$ and representative members of the $\gamma$ subdivision of the Proteobacteria. Bar $=5 \%$ nucleotide change per $16 \mathrm{~S}$ rRNA position.

designated FL5. The DNA base compositions of the Puget Sound strains and Methylomonas methanica differ substantially (37 to 38 and $52 \mathrm{~mol} \%$, respectively). Furthermore, strains PS- ${ }^{\mathrm{T}}$, PS-2, and PS-3 do not utilize methane or other $\mathrm{C}_{1}$ compounds as carbon sources and do not contain intracytoplasmic membranes under the growth conditions which we used. The symbionts of marine bivalves have not been cultivated. These organisms and members of the genus Thiomicrospira are sulfur-oxidizing bacteria, but our strains do not utilize thiosulfate as an energy source. Our strains also are not closely related to other marine genera of aerobic, heterotrophic, motile, rod-shaped bacteria belonging to the $\gamma$ subdivision of the Proteobacteria. A similarity matrix revealed that, although the Puget Sound strains exhibit levels of base homology to one another of more than $99 \%$ (data not shown), they are less than 90\% similar to their closest relatives (Table 3).

Table 4 summarizes phenotypic information for marine, rod-shaped, aerobic, heterotrophic genera belonging to the $\gamma$ subdivision of the Proteobacteria, including the genera Alteromonas, Oceanospirillum, Vibrio, and Methylomonas. It is apparent from the properties shown in Table 4 and the differences in $16 \mathrm{~S}$ rRNAs that the aromatic hydrocarbon-degrading strains isolated from Puget Sound cannot be assigned to any previously recognized bacterial genus. Therefore, we describe a new genus for these bacteria below.

Description of Cycloclasticus gen. nov. Cycloclasticus (Cy.clo. clas' ti.cus. Gr. n. kyklos, circle or ring; Gr. adj. klastos, broken; M. L. masc. n. cycloclasticus, ring breaker). Gram-negative, rod-shaped cells that are 0.5 by 1 to $2 \mu \mathrm{m}$. Motile by means of a single polar flagellum. Obligately aerobic, oxidase positive, and catalase positive. Strains utilize aromatic compounds, including biphenyl, naphthalene, anthracene, and phenanthrene, as sole or principal sources of carbon and energy.

The $\mathrm{G}+\mathrm{C}$ contents of strains of the single species range from 37 to $38 \mathrm{~mol} \%$.

The type and only species of the genus is Cycloclasticus pugetii.
Description of Cycloclasticus pugetii sp. nov. Cycloclasticus pugetii sp. nov. (pu.get'i.i. M. L. gen. n. pugetii, of Puget, named in honor of Peter Puget, a British naval officer who participated in the Vancouver Expedition and for whom Puget Sound was named; Puget Sound is a large, deep, marine body of water and associated estuaries which is located in western Washington and extends south of the Strait of Juan de Fuca).

Rods that are motile by means of a single polar flagellum. Aerobic. Requires at least $10 \%$ salinity for growth. Catalase and oxidase positive. Grows poorly on complex bacteriological media containing no aromatic compounds. Aromatic compounds, including biphenyl, naphthalene, phenanthrene, anthracene, and toluene, are used as sole or principal carbon sources for growth. In addition, strains utilize selected fatty acids and amino acids, including acetate, propionate, and glutamate. Nitrate is reduced to nitrite. Colonies are small, round, and entire with no pigmentation, and a yellow diffusible compound is produced during growth on biphenyl. The prin-

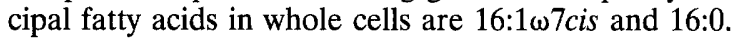

The type strain, $C$. pugetii PS-1, was isolated from the surface sediments of Sinclair Inlet, which is located on Puget Sound near the city of Bremerton, Wash.

The $\mathrm{G}+\mathrm{C}$ content is $37 \mathrm{~mol} \%$.

C. pugetii $\mathrm{PS}-1^{\mathrm{T}}$ has been deposited in the American Type Culture Collection as strain ATCC $51542^{\mathrm{T}}$.

It is significant that members of this genus of aerobic, gram-negative rods could not be identified without sequencing their $16 \mathrm{~S}$ rRNAs. On the basis of phenotypic test and DNA base composition results, these organisms would have been most logically placed in the genus Alteromonas. Thus, the use of 16S rRNA sequencing was critical for the correct placement of this genus in its appropriate phylogenetic position. It is also noteworthy that, if this bacterium had not been isolated but simply had had its sequence determined as a clone from natural samples collected from the marine environment, it may have been described as a lithotrophic bacterium most closely 


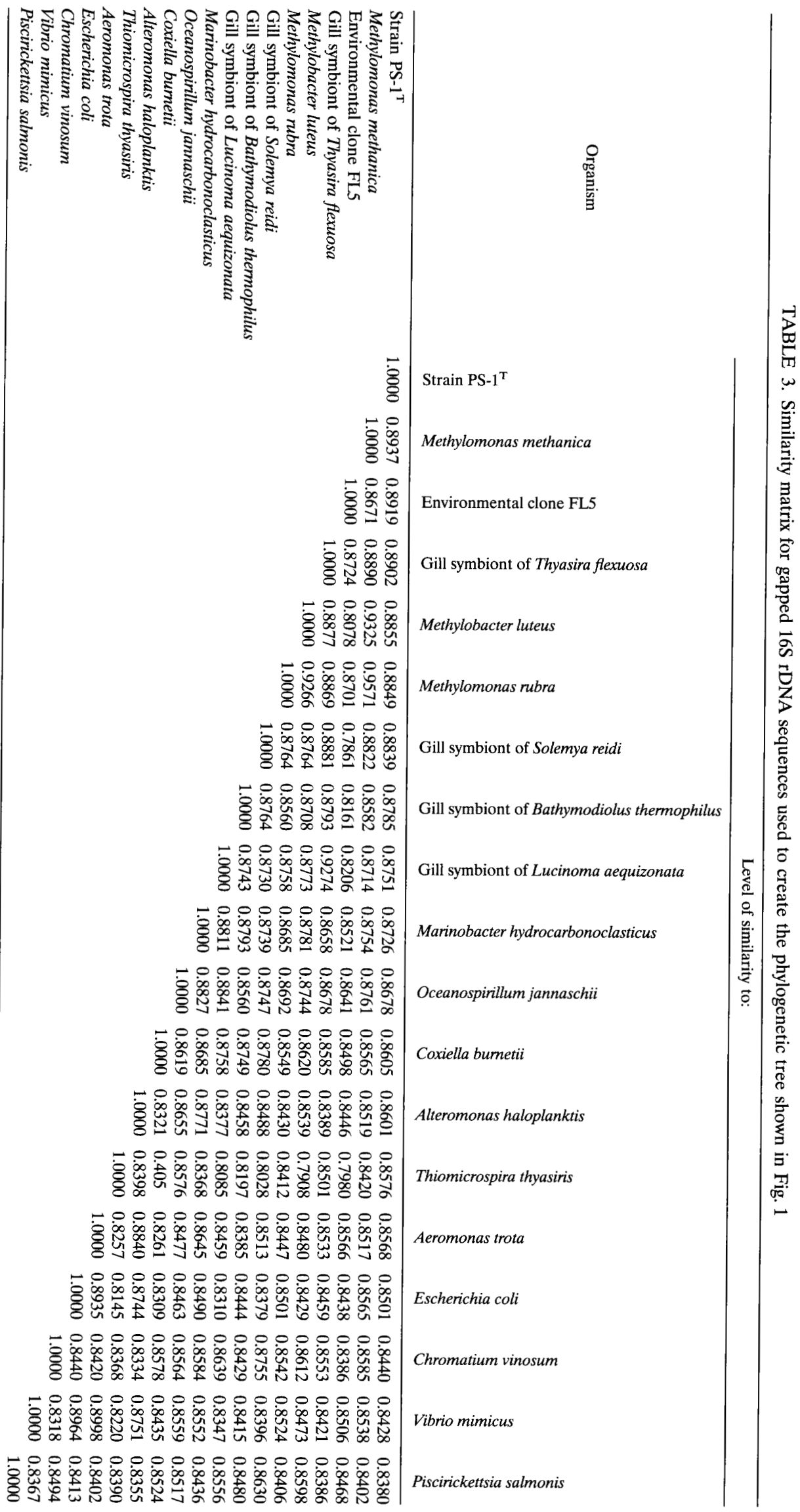


TABLE 4. Comparison of key phenotypic characteristics of the genus Cycloclasticus and other aerobic, rod-shaped, marine heterotrophic bacteria that are members of the $\gamma$ subdivision of the Proteobacteria ${ }^{a}$

\begin{tabular}{|c|c|c|c|c|c|c|}
\hline Characteristic & Cycloclasticus & Alteromonas & $\begin{array}{c}\text { Oceanospirillum } \\
\text { kriegii }\end{array}$ & $\begin{array}{l}\text { Oceanospirillum } \\
\text { jannaschii }\end{array}$ & Vibrio & Methylomonas \\
\hline Cell shape & Straight rods & Straight rods & Straight rods & Straight rods & $\begin{array}{l}\text { Curved to straight } \\
\text { rods }\end{array}$ & $\mathrm{NR}^{b}$ \\
\hline Motility & + & + & + & + & + & + \\
\hline Flagellar arrangement & Polar, single & Polar, single & Polar, single & Polar, 1 or 2 & Polar & Polar \\
\hline Cell dimensions $(\mu \mathrm{m})$ & $0.5 \times 1.0-2.0$ & $0.7-1.5 \times 1.8-3.0$ & $0.8-1.2 \times 2.6-3.6$ & $1.0-1.4 \times 2.4-3.2$ & $0.5-0.8 \times 1.4-2.6$ & $0.5-1.0 \times 1.0-4.0$ \\
\hline $\begin{array}{l}\text { Poly- } \beta \text {-hydroxybutyrate } \\
\text { accumulation }\end{array}$ & - & - & + & + & $\mathbf{D}^{c}$ & - \\
\hline Intracellular membranes & - & - & - & NR & - & + \\
\hline Susceptibility to $\mathrm{O} / 129$ & $\begin{array}{l}\text { Resistant to } 10 \mu \mathrm{g} \text {, sus- } \\
\text { ceptible to } 150 \mu \mathrm{g}\end{array}$ & NR & NR & NR & $\mathrm{D}$ & NR \\
\hline $\begin{array}{l}\mathrm{Na}^{+} \text {required or stimulates } \\
\text { growth }\end{array}$ & + & + & + & + & + & $+^{d}$ \\
\hline $\mathrm{NO}_{3}^{-}$reduced to $\mathrm{NO}_{2}^{-}$ & + & - & - & + & $t^{e}$ & NR \\
\hline Acid produced from glucose & $\mathrm{NG}^{f}$ & NR & NR & NR & + & NR \\
\hline Oxidase & + & + & + & + & $+g$ & + \\
\hline Amylase & - & $\mathrm{D}$ & NR & NR & $\mathrm{D}$ & NR \\
\hline Lipase & + & + & + & - & $\mathrm{D}$ & NR \\
\hline Gelatinase & - & + & - & - & $\mathrm{D}$ & NR \\
\hline \multicolumn{7}{|l|}{ Utilization of: } \\
\hline D-Glucose & - & + & + & - & + & - \\
\hline D-Fructose & - & D & + & - & + & - \\
\hline D-Mannitol & - & $\mathrm{D}$ & + & - & $t^{h}$ & - \\
\hline DL-Malate & - & NR & + & - & $+^{i}$ & - \\
\hline$\alpha$-Ketoglutarate & - & NR & + & + & + & - \\
\hline Methane & - & - & - & - & - & + \\
\hline Methanol & - & - & - & - & NR & + \\
\hline $\begin{array}{l}\mathrm{G}+\mathrm{C} \text { content of DNA } \\
(\mathrm{mol} \%)\end{array}$ & $37-38$ & $38-50$ & NR & NR & $38-51$ & 52 \\
\hline
\end{tabular}

${ }^{a}$ The data for Oceanospirillum kriegii, Oceanospirillum jannaschii, and the genera Alteromonas, Vibrio, and Methylomonas were obtained from references 22 and 25.

${ }^{b} \mathrm{NR}$, not reported.

${ }^{c} \mathrm{D}$, different species give different results.

${ }^{d}$ Data for Methylomonas pelagica.

${ }^{e}$ Negative for Vibrio gazogenes, Vibrio metschnikovii, Vibrio ordalii, and Vibrio salmonicida.

${ }^{f} \mathrm{NG}$, no growth.

${ }^{g}$ Negative for Vibrio gazogenes and Vibrio metschnikovii.

${ }^{h}$ Negative for Vibrio (Listonella) damsela, Vibrio marinus, Vibrio nereis, and Vibrio ordalii.

${ }^{i}$ Negative for Vibrio (Listonella) pelagia, Vibrio ordalii, Vibrio logei, Vibrio costicola, and Vibrio fischeri.

related to sulfur oxidizers or methane oxidizers. Thus, an analysis of the $16 \mathrm{~S}$ rRNA sequence alone would not have permitted meaningful characterization of the metabolic capabilities of the organism.

\section{ACKNOWLEDGMENTS}

This work was supported by grants N00014-91-J-1792 and N0001492-J-1578 from the Office of Naval Research.

Sediments from sites 1 and 3 were collected with the assistance of personnel from the U.S. Navy and the Army Corp of Engineers, respectively. Internal sequencing primers were kindly provided by Romesh K. Gautom and Thomas R. Fritsche, University of Washington. We thank Sue Barns, Department of Biology, Indiana University, for many suggestions regarding PCR and 16S rDNA sequencing. Gary Olsen, RDP, offered suggestions and kindly provided an unreleased version of DNAml rates, a computer program to calculate category rates that is used with fastDNAml. Mary Kuhner and Joe Felsenstein, University of Washington, provided helpful insights into phylogenetic analysis.

\section{REFERENCES}

1. Ahmad, D., M. Sylvestre, M. Sondossi, and R. Mass'e. 1991. Bioconversion of 2-hydroxy-6-oxo-6-(4'-chlorophenyl)hexa-2,4-dienoic acid, the metacleavage product of 4-chlorobiphenyl. J. Gen. Microbiol. 137:1375-1385.

2. Ausubel, F. M. 1994. Current protocols in molecular biology. John Wiley \& Sons, Inc., New York.

3. Barns, S. (Department of Biology, Indiana University, Bloomington). 1993. Personal communication.

4. Baumann, L., P. Baumann, M. Mandel, and R. D. Allen. 1972. Taxonomy of aerobic marine eubacteria. J. Bacteriol. 110:402-429.

5. Biddell, J. P., and S. Spotte. 1985. Artificial seawaters. Jones and Bartlett Publisher, Inc., Boston.

6. Bratina, B. J., G. A. Brusseau, and R. S. Hanson. 1992. Use of 16S rRNA analysis to investigate phylogeny of methylotrophic bacteria. Int. J. Syst. Bacteriol. 42:645-648.

7. Brosius, J., M. L. Palmer, P. J. Kennedy, and H. F. Noller. 1978. Complete nucleotide sequence of a $16 \mathrm{~S}$ ribosomal RNA gene from Escherichia coli. Proc. Natl. Acad. Sci. USA 75:4801-4805.

8. DeLong, E. F., D. G. Franks, and A. L. Alldredge. 1993. Phylogenetic diversity of aggregate-attached vs. free-living marine bacterial assemblages. Limnol. Oceanogr. 38:924-934.

9. Distel, D. L., D. J. Lane, G. J. Olsen, S. J. Giovannoni, B. Pace, N. R. Pace, D. A. Stahl, and H. Felbeck. 1988. Sulfur-oxidizing bacterial endosymbionts: analysis of phylogeny and specificity by $16 \mathrm{~S}$ rRNA sequences. J. Bacteriol. 170:2506-2510.

10. Distel, D. L., and A. P. Wood. 1992. Characterization of the gill symbiont of Thyasira flexuosa (Thyasiridae: Bivalvia) by use of polymerase chain reaction and 16S rRNA sequence analysis. J. Bacteriol. 174:6317-6320.

11. Evans, P. J., D. T. Mang, K. S. Kim, and L. Y. Young. 1991. Anaerobic degradation of toluene by a denitrifying bacterium. Appl. Environ. Microbiol. 57:1139-1145.

12. Fryer, J. L., C. N. Lannan, S. J. Giovannoni, and N. D. Wood. 1992 Piscirickettsia salmonis gen. nov., sp. nov., the causative agent of an epizootic disease in salmonid fishes. Int. J. Syst. Bacteriol. 42:120-126.

13. García-Valdés, E., E. Cozar, R. Rotger, J. Lalucat, and J. Ursing. 1988. New naphthalene-degrading marine Pseudomonas strains. Appl. Environ. Microbiol. 54:2478-2485.

14. Gauthier, M. J., B. Lafay, R. Christen, L. Fernandez, M. Acquaviva, P. Bonin, and J. C. Bertrand. 1992. Marinobacter hydrocarbonoclasticus gen. nov., sp. nov., a new, extremely halotolerant, hydrocarbon-degrading marine bacterium. Int. J. Syst. Bacteriol, 42:568-576.

15. Gautom, R. K., and T. R. Fritche (Department of Microbiology, University of Washington, Seattle). 1993. Personal communication. 
16. Genetics Computer Group. 1993. Fragment assembly computer programs. Genetics Computer Group, Madison, Wisc.

17. Gerhardt, P., R. G. E. Murray, W. A. Wood, and N. R. Krieg (ed.). 1994. Methods for general and molecular bacteriology. American Society for Microbiology, Washington, D.C.

18. Ghosh, D. K., and A. K. Mishra. 1983. Oxidation of phenanthrene by a strain of Micrococcus: evidence of protocatechuate pathway. Curr. Microbiol. 9:219-224.

19. Gilbert, D. G. 1992. SeqApp, a biological sequence editor and analysis program for Macintosh computers. Published electronically on the Internet, available via anonymous ftp to ftp.bio.indiana.edu.

20. Guerin, W. F., and G. E. Jones. 1988. Mineralization of phenanthrene by a Mycobacterium sp. Appl. Environ. Microbiol. 54:937-944.

21. Heitkamp, M. A., W. Franklin, and C. E. Cerniglia. 1988. Microbial metabolism of polycyclic aromatic hydrocarbons: isolation and characterization of a pyrene-degrading bacterium. Appl. Environ. Microbiol. 54:25492555.

22. Herwig, R. P., and J. T. Staley. 1986. Anaerobic bacteriology of the intestinal tracts of Icelandic fin whales. FEMS Microbiol. Ecol. 38:361-371.

23. Holt, J. G., N. R. Krieg, P. H. A. Sneath, J. T. Staley, and S. T. Williams (ed.) 1994. Bergey's manual of determinative bacteriology, 9th ed. Williams \& Wilkins, Baltimore.

24. Jerina, D. M., H. Selander, H. Yagi, M. C. Wells, J. F. Davey, V. Mahadevan, and D. T. Gibson. 1976. Dihydrodiols from anthracene and phenanthrene. J. Am. Chem. Soc. 98:5988-5996.

25. Kiyohara, H., K. Nagao, K. Kouno, and K. Yano. 1982. Phenanthrenedegrading phenotype of Alcaligenes faecalis AFK2. Appl. Environ. Microbiol. 43:458-461.

26. Krieg, N. R., and J. G. Holt (ed.). 1984. Bergey's manual of systematic bacteriology, vol. 1. The Williams \& Wilkins Co., Baltimore.

27. Larsen, N., G. J. Olsen, B. L. Maidak, M. J. McCaughey, R. Overbeek, T. J. Macke, T. L. Marsh, and C. R. Woese. 1993. The ribosomal database project Nucleic Acids Res. 21:3021-3023.

28. Leahy, J. G., and R. R. Colwell. 1990. Microbial degradation of hydrocarbons in the environment. Microbiol. Rev. 54:305-315.

29. Manafi, M., and W. Kneifel. 1990. Rapid methods for differentiating Gram-positive from Gram-negative aerobic and facultative anaerobic bacteria. J. Appl. Bacteriol. 69:822-827.
30. Martinez-Murcia, A. J., S. Benlloch, and M. D. Collins. 1992. Phylogenetic interrelationships of members of the genera Aeromonas and Plesiomonas as determined by $16 \mathrm{~S}$ ribosomal DNA sequencing: lack of congruence with results of DNA-DNA hybridizations. Int. J. Syst. Bacteriol. 42:412-421.

31. MIDI, Inc. 1993. Microbial Identification System operating manual, version 4. MIDI, Inc., Newark, Del.

32. Mueller, J. G., P. J. Chapman, B. O. Blattmann, and P. H. Pritchard. 1990. Isolation and characterization of a fluoranthene-utilizing strain of Pseudomonas paucimobilis. Appl. Environ. Microbiol. 56:1079-1086.

33. Nestler, F. H. M. 1974. Characterization of wood-preserving coal-tar creosote by gas-liquid chromatography. Anal. Chem. 46:46-53.

34. Okpokwasili, G. C., C. C. Somerville, D. J. Grimes, and R. R. Colwell. 1986. Plasmid-associated phenanthrene degradation by Chesapeake Bay sediment bacteria. A. Colloq. Inst. Fran. Rech. Exploit. Mer 3:601-610.

35. Olsen, G. J. 1993. DNAml rates 1 0. University of Illinois, Urbana.

36. Olsen, G. J., H. Matsuda, R. Hagstrom, and R. Overbeek. 1994. fastDNAml: a tool for construction of phylogenetic trees of DNA sequences using maximum likelihood. CABIOS 10:41-48.

37. Reysenbach, A. L., L. J. Giver, G. S. Wickham, and N. R. Pace. 1992. Differential amplification of rRNA genes by polymerase chain reaction. Appl. Environ. Microbiol. 58:3417-3418.

38. Ruimy, R., V. Breittmayer, P. Elbaze, and B. Lafay. Unpublished data.

39. Shelton, D. R., and J. M. Tiedje. 1984. Isolation and partial characterization of bacteria in an anaerobic consortium that mineralizes 3-chlorobenzoic acid. Appl. Environ. Microbiol. 48:840-848.

40. Staley, J. T. 1968. Prosthecomicrobium and Ancalomicrobium: new freshwater prosthecate bacteria. J. Bacteriol. 95:1921-1942.

41. Stein, J. E., W. L. Reichert, M. Nishimoto, and U. Varanasi. 1990. Overview of studies on liver carcinogenesis in English sole from Puget Sound; evidence for a xenobiotic chemical etiology. II. Biochemical studies. Sci. Total Environ. 94:51-69.

42. Varanasi, U., and J. E. Stein. 1991. Disposition of xenobiotic chemicals and metabolites in marine organisms. Environ. Health Perspect. 90:93-100.

43. West, P. A., G. C. Okpokwasili, P. R. Brayton, D. J. Grimes, and R. R. Colwell. 1984. Numerical taxonomy of phenanthrene-degrading bacteria isolated from the Chesapeake Bay. Appl. Environ. Microbiol. 48:988-993.

44. Woese, C. R. Unpublished data. 